\section{Molecular characterization of the chicken anemia virus by using the VP1 gene of CAV/ SK/2017 strains, Iraq}

\section{ABSTRACT}

Chicken infectious anemia virus (CIAV) is one amongst the numerous pathogens in the poultry industry. CIAV infection can cause restraint of the immune system, the excitement of co-infections, vaccination failures and mortality. chicks. Maternal antibodies not prevent infection but to prevent these symptoms, immunological disorder, or transmission of the virus. Genetic characterizations for five sequences of chicken infectious anemia virus (CIAV) from different flocks of broiler industrial chickens were a consideration for the primary time in Iraq. Phylogenetic analysis of the viral protein 1 (VP1) gene, as well as the hypervariable region of the CIAV genome, indicated that Iraqi CIAV strains have belonged into genotype II. Amino acid comparison exhibit that the diversity of VP1 is indicated that the new strains were extremely pathogenic viruses. Our epidemiological study provided new insights into the prevalence of CIAV strain in recent years in Sulaimani province/Iraq.

Keywords: Viral protein (VP1), viral evolution, phylogenetic analysis

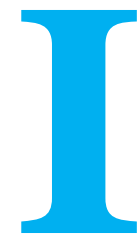

ntroduction

Chicken infection anemia virus (CIAV) is a Gyrovirus belonging to the family Circoviridae. The agent is a nonenveloped, initial isolated by (Yuasa et al., 1979; Hailemariam et al., 2008). The genome consists of a single molecule of circular (covalently closed end) negative-sense single-stranded DNA (Gelderblom et al., 1989; Murphy et al., 1999). CIAV is associate degree economically necessary microorganism with a worldwide distribution. CIAV infections are manifested by either clinical or subclinical signs. (Schat, 2004). The clinical symptoms are mainly perceived in young chicks of 10-14 days of age that typically acquire the infection vertically. (Adair, 2000). The arrangement of the genome consists of three overlapping open reading frames (ORFs) encoding three viral proteins: VP2, a dual-specificity phosphatase This was the first dual specificity protein phosphatases gene to be identified in a small viral genome (Noteborn et al., 1998; Peters et al., 2006).

\section{How to cite this article}

Omar baba sheikh, M. (2019). Molecular characterization of the chicken anemia virus by using the VP1 gene of CAV/ SK/2017 strains, Iraq J Adv VetBio Sci Tech, 4(3), 72-79. https://doi.org/10.31797/vetbio.555294

\section{Research Article}

\section{Mohammed Omar baba sheikh}

Department of Molecular biologyveterinary laboratory centre, Sulaimani veterinary directorate ORCID - 0000-0002-0503-5267

\section{Correspondence}

Sulaimani Veterinary directorate, Shekh mhedin, Sulaimani, Kurdistan region, Iraq muhamad.omer@ymail.com 009647701571458

Article info Submission: 17-04-2019 Accepted: 07-10-2019 Online first published: 25-10-2019 Published: 30-12-2019

This work is licensed under a Creative Commons Attribution 4.0 International

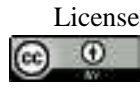

e-ISSN: $2548-1150$ website: http://dergipark.gov.tr/vetbio doi prefix: $10.31797 /$ vetbio. 
VP3, additionally called poptin, that has been shown to possess apoptotic activity in transformed cell lines (Jeurissen et al., 1992), and VP1, the foremost capsid protein, a larger region of the genome that contains the hypervariable region in additionally to upstream amino acid differences; so, it's typically used for genetic characterization and molecular studies. (Craig et al., 2009; Renshaw et al., 1996). In classical CIAV, has three genetically distinct genotypes (I, II, and III) have been recognized through phylogenetic analysis based on the VP1 gene (Islam et al., 2002; Snoeck et al., 2012). Genotypes II and III are rumored to be distributed worldwide, whereas genotype I consist alone of isolates from Australia (Kim et al., 2010). In Iraq, the primary has reported the detection of CIAV in broiler chicken (AlAl-Mohana, al., 2013) but, genetic characterization from Iraq isolates has not been reported. This study describes the CIAV in 4, 10, 14 day-old commercial broilers and also the detection of CIAV DNA in tissues. A virus strain was genetically characterized in a part of the VP1 gene for the first time in Iraq, and the extent of genetic variation among the current strains and Global relationship with other CIAV strains was analyzed. Moreover, we tend to compare the particular amino acids region in VP1 that determined the virulence of CIAV.

\section{MATERIAL METHODS}

\section{Samples and DNA extraction}

Tissue (liver, spleen, and bursa) samples were obtained from clinical and subclinical 10 broiler flock in Sulaimani province between the ages of (4, 10 and 14) days. The samples were collected during the April 2016 to June 2017 and directly sent them to Sulaimani veterinary diagnostic laboratory. The CIAV DNA was extracted from pooled samples of each flock using extraction kit for tissue (Genet-Bio Republic Korea) from the homogenized liver, bursa, and spleen of chickens.

\section{Virus DNA amplification by PCR}

The extracted DNA was amplified using the primers CAV1 and CAV2 for PCR covering a 387-nucleotide region in the highly conserved overlapping sequence of VP2 (Cardona et al, 2000,; KUMAR. 2007), anemia $f$ and anemia $r$ for PCR product of 675 bp (Marin et al, 2012; AboElkhair et al, 2014) of partial VP1 genes (Table 1). The PCR amplification was performed in a $20 \mu \mathrm{l}$ volume by using PCR Premix (2X). This kit provides a complete system for fast, high yield and reliable single tube one (Genetbio, Korea). The amplification was performed with the Thermal Cycle (Hercuvan, USA). The PCR profile of CAV1 and CAV2 primers was pre-denaturated at $94^{\circ} \mathrm{C}$ for $5 \mathrm{~min}$, followed by 35 cycles of denaturation, annealing and extension at $94^{\circ} \mathrm{C}$ for $30 \mathrm{sec}, 60^{\circ} \mathrm{C}$ for $30 \mathrm{sec}$ and $72^{\circ} \mathrm{C}$ for 30 sec respectively. and a final extension of $72^{\circ} \mathrm{C}$ for $5 \mathrm{~min}$. The reaction of Anemia $f$ and Anemia $r$ primers was performed by denaturation at $94^{\circ} \mathrm{C}$ for $5 \mathrm{~min}$, followed by 40 cycles of denaturation, annealing and extension at $94^{\circ} \mathrm{C}$ for $30 \mathrm{sec}, 60^{\circ} \mathrm{C}$ for $30 \mathrm{sec}$, $72^{\circ} \mathrm{C}$ for $40 \mathrm{sec}$ and a final extension $72^{\circ} \mathrm{C}$ for five min. The PCR products were analyzed by electrophoresis on a $1 \%$ agarose gel and visualized on Gel Documentation (UVtec, UK).

Table: 1 Primer oligonucleotide employed for CIAV

\begin{tabular}{|lllll|}
\hline Primer & sequences & bp & position & target gene \\
\hline CAV1-F & CAAGTA ATT TCA AAT GA A CG & 387 & & VP2 \\
\hline $\begin{array}{l}\text { anemia-F } \\
\text { anemia-R }\end{array}$ & TTG CCA TCT TAC AGT CTT AT & & & VP1 \\
\hline
\end{tabular}


Sequences analysis and Phylogenetic tree Nucleotide sequence alignments, emendation, and amino acid prognosis of just about the partial region of the VP1 gene were performed using Clustalw (Thompson et al., 1994). The predicted amino acid and nucleotide sequences of 5 CIAV were determined and compared. The MEGA 7.0 software system using for phylogenetic trees were generated by the neighbor-joining method (Tamura et al., 2013) with 1000 bootstrap replications. Sequences data were submitted to GenBank with accession numbers MH095973 to

MH095977, KY399853, and KY399854

\section{RESULT}

\section{CIAV Identification}

7 samples were screened by PCR assay using cav1 \& cav2 primer pairs and expected size 387bp (Figure 1). Only five samples were found to be positive using the anemia primer pair and expected the size of 675 bp (Figure 2 ). The positive case as well as all age of the flock that employed in this study.
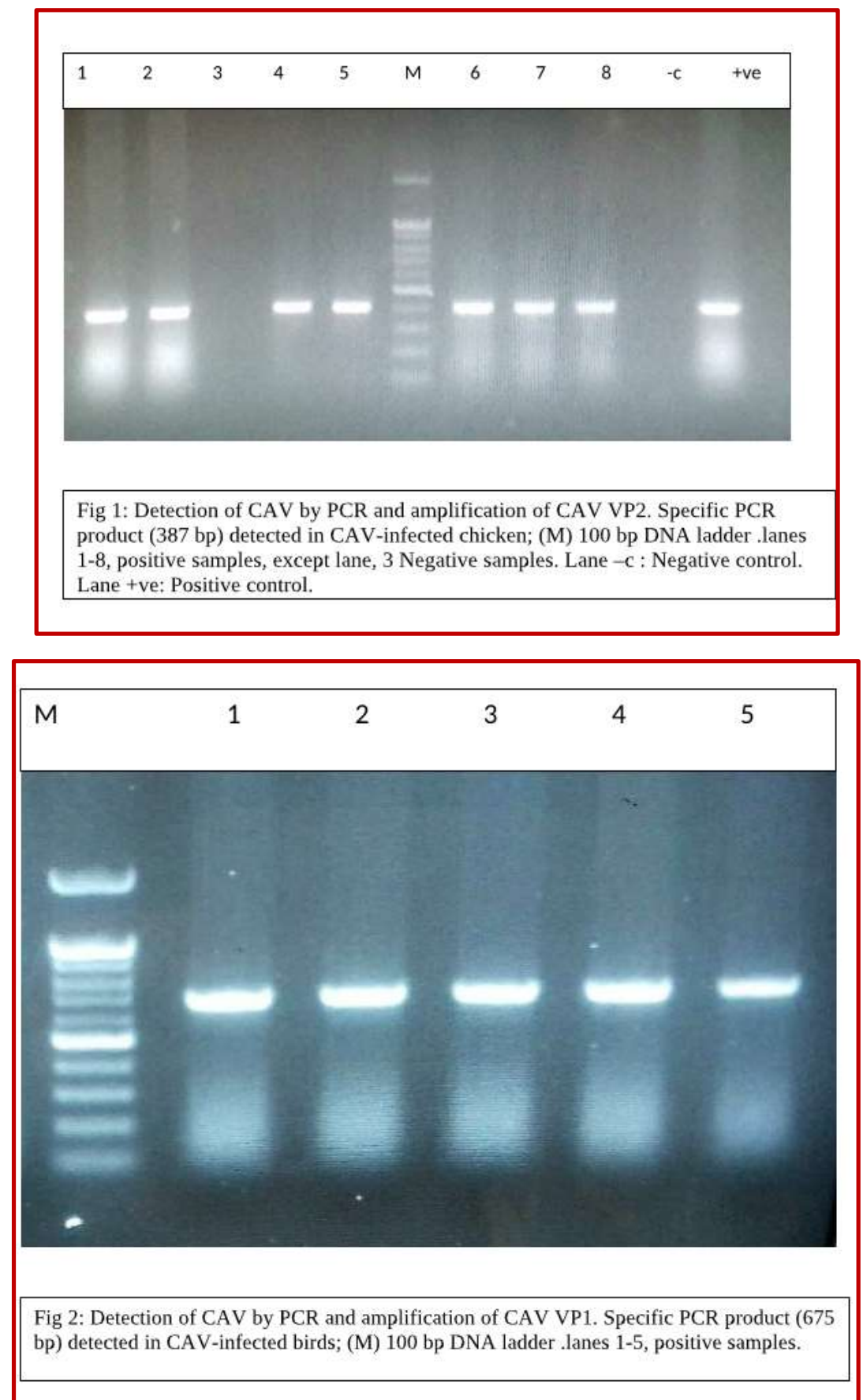
The obtained nucleotide and amino acid sequences of five CIAV partial VP1 genes during this study were compared with different CIAV reference strain in GenBank by multiple alignments with the ClustalW enclosed in MEGA.7 software. The five nucleotide sequences of detected CAV displayed a restricted diversity were closely associated with one another with identity 9799\% whereas amino acid identity $97-100 \%$ among them. The nucleotide sequence identities between the five CIAV isolate partial VP1 and $35 \mathrm{CAV}$ isolates retrieved from GenBank ranged between 93.36\% and 98.24\%. The highest identity (98.24\%) was found between the chicken CIAV isolates and IR4-CIAV (accession no. KU195692, isolated from Iran, in 2013). The lowest identity (93.36\%) was found between the chicken CIAV isolates and CAU269/7 (accession no. AF227982, isolated from Australia in 2000). Interestingly, compare amino acid sequences of those isolate with three industrial vaccines (Del rose and Cux-1, NobilP4vac) strains, exhibit homology around (95.5-97\%, 95$96.5 \%$, and $94.5-96 \%$ ) respectively. See (Table 2). Multiple sequences alignment of five CIAV strains with six references strains as well as 3 industrial vaccines within the (positions 139-151), and virulence-associated motif (Kye et al, 2013; Todd et al., 2002) positions $75,89,125,139,141$, and 144 in the VP1 protein, all Iraqi CIAV that were conserved among genotype II viruses and given I, T, I, Q,Q,Q respectively as the majority of virulent strains (Figure.4). Phylogenetic analysis of the VP1 nucleotide sequences by neighbor-joining separated the CAV strains into 3 distinct genotypes: I, II, and III, (Ducatez et al.,2006; Snoecket al., 2012). The phylogenetic analysis of the partial VP1 gene sequence of CIAV and strains in this study showed that five field virus sequences belonged to (Genotype II) and were clustered with (CAVb/Brzl, /IR5-CAV and /GD/China) isolates, (Figure.3), however Five field virus amino acid sequences it's to create divergence when compared with three genotypes (II, III and I) ranged around (2.4\%, $4 \%$, and $4.5 \%$ ) respectively.

\section{DISCUSSION}

CIAV is an economically important pathogen worldwide due to its highly immunosuppressive effect. In Iraq, CIAV was first reported in 2012 (Al-Mohana et al., 2013). within the current study, Out of 10 tissue homogenate were examined and investigated for the presence of CIAV DNA, seven samples were positive with proportion seventieth, It confirmed that CIAV is widely distributed among chicken flocks in Sulaimani province, This result suggests that CIAV can be concerned in inflicting subclinical infections. Attributable to the widespread application of vaccination for breeders and therefore the presence of maternal antibodies, the clinical type of CIAV is rare (Sommer and Cardona, 2003).

Phylogenetic analysis of the VP1 sequences classifying CIAV genetically into 3 distinct genotypes (I, II, and III), all isolated during this study clustered with genotype II (Figure 3 ), this result indicated that Genotype II more prevalence in Iraq. The genetic variations of CIAV are determined depending on the sequence of the VP1 gene which contains the hypervariable region in between the amino acid residues 139-151 (Kye et al, 2013), additionally to be the presence of the genetic determinates of CAIV virulence. The amino acid motif of the highly pathogenic CIAV as I75, T89, I125, 139, Q141, and Q144 strains (Abdel-Mawgod et al., 2018). A comparison with the VP1 sequence of Iraqi CIAV in this study, it had been found that the five field virus sequences contain the motif of highly pathogenic viruses (Figure. 4). Vaccination of poultry trade presently isn't promptly obtainable, the topology of the phylogenetic tree showed that the CIAV Iraqi sequences are 
in a distant relationship with different vaccine strains commercially used, for example, DelRos, Nobilis P4, and Cux-1. All five isolate CAV sequences are enclosed in cluster II, whereas vaccine strains are located in cluster
III. Nevertheless, Del-Ros vaccine strain is considered as an appropriate one of the best choice strains for induction in vaccine when compared to the other two vaccine strains (Nobilis P4, and Cux-1).

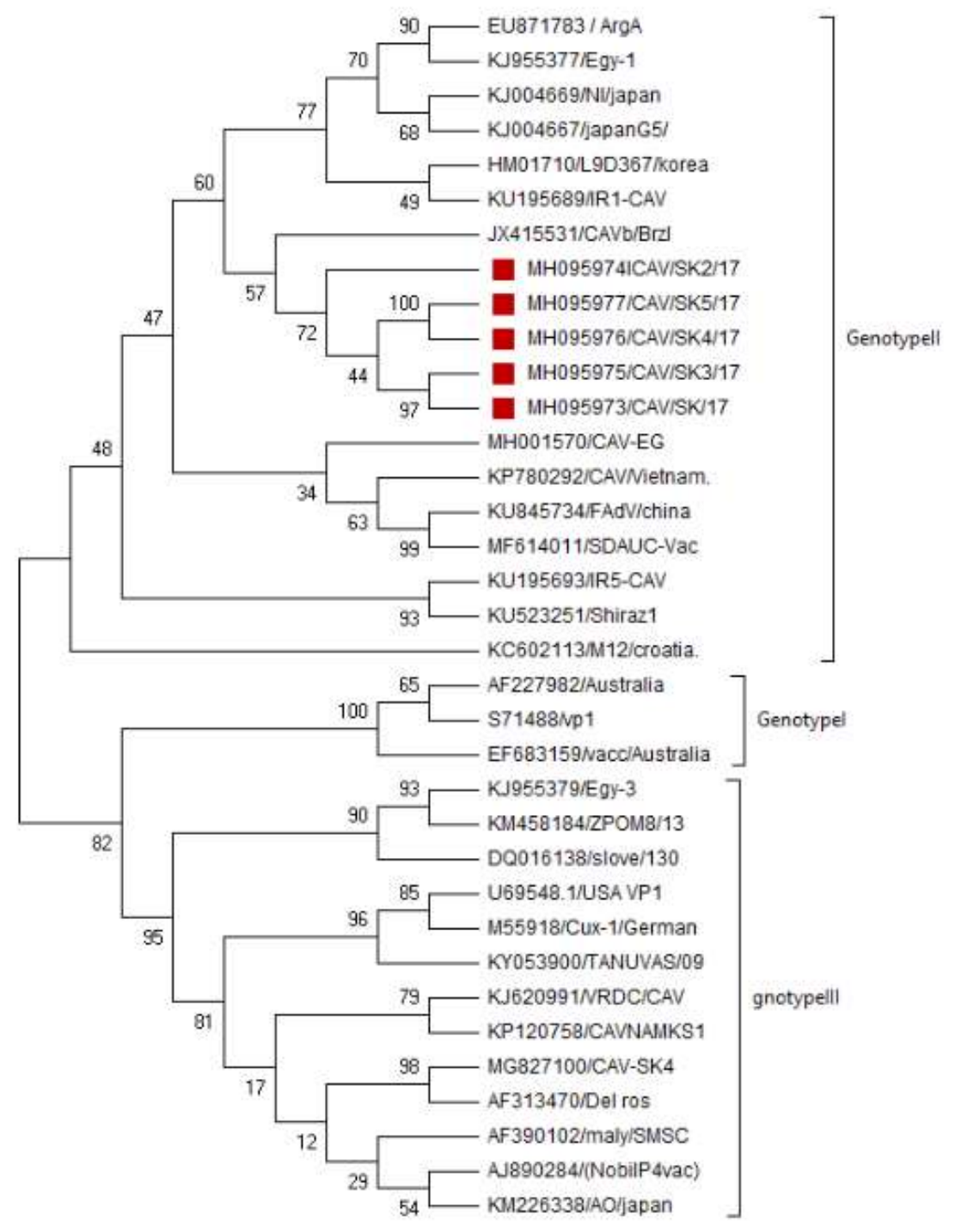

Fig 3. Phylogenetic trees of Cambodian chicken anemia virus (CAV) isolates based on comparison of the partial viral protein1 (VP1) gene sequences of representative CAV strains $(n=35)$. Tree construction was done using the neighbor-joining method with 1,000 replicates. The Iraqi sequences obtained in the present study are red square. 
Table 2. Identities between CAVL/SK/2017 strains and different Genotype related isolates obtained from sequence comparison

\begin{tabular}{|lllll|}
\hline ACCESION NO. & STRAIN & GENOTYPE & DNA Identity & a.a identity \\
\hline AJ890284 & NobilP4vac & III & $94-95 \%$ & $94.5-96 \%$ \\
AF313470 & Del_ros & III & $94.5-95 \%$ & $95.5-97 \%$ \\
M55918 & Cux-1 & III & $94.30 \%$ & $95-96.5 \%$ \\
EU871783 & ArgA & II & $96-97 \%$ & $97.5-99 \%$ \\
KU845734 & FAdV/china & II & $97 \%$ & $96.5-98 \%$ \\
JX415531 & CAVb/Brzl & II & $97.5 \%$ & $97.5-99 \%$ \\
KU195693 & IR5-CAV & II & $97.5 \%$ & $97.5-99 \%$ \\
KC691411 & CMB11090 & II & $96.5-975$ & $97.5-99 \%$ \\
\hline EF683159 & vacc/Australia & I & 94.55 & $95-97 \%$ \\
AF390102 & Malaysia/SMSC & III & $94 \%$ & $94.5-96 \%$ \\
DQ016138 & slove/130 & III & $95 \%$ & $97-99 \%$ \\
\hline
\end{tabular}

According to the history, the virus strain was imported through a trade of eggs from unvaccinated breeders. Veterinarians and breeders ought to perceive the need for vaccination to eliminate economic losses caused by CIAV infections. Additionally, imported eggs and breeders should come from flocks vaccinated against CIAV.

Management assessment is critical, because CIAV is a very resistant virus to the environment, and CIAV has worldwide distribution. It's terribly troublesome to eradicate the disease, however, a vaccinationprimarily based strategy and serological tests can facilitate to regulate CIAV infections in young birds. Studies have exhibited the presence of clinical disease associated with CIAV infection in 2-to-4- wk-old broilers from vaccinated parent flocks (Brentano et al., 2005). The information questions the role of maternal immunity in the prevention of transmission and development of clinical illness in young chicks and complicates the role of control measurements.
In conclusion, the results of this study indicate that CIAV exists in Iraq broiler farm and could have an economic impact on the poultry trade, Epidemiological studies on an outsized scale are required to evaluate the distribution of CIAV infections in Iraq poultry industry, Moreover, our results counsel that an extra study of the CIAV vaccine is also required to elucidate the relationship between vaccine efficaciousness and local strains in Iraq, in addition as additional studies associated with reversion of vaccine.

\section{Acknowledgement}

The author is highly thankful to Sulaimani Veterinary Diagnosis Laboratory (SVDL) for providing research area, financial support and other necessary facilities to carry out the study.

\section{Conflicts of interest}

The author declares that there is no conflict of interest. 
61

75

89

MHO95977/CAV/SK LPNPQSTMTIRFQGIIFLAEGFILPKNSTAGGYADHLYGARVAKISVNLKEFLLASMNLT MH095976/CAV/SK LPNPQSTMTIRFQGIIFLAEGFILPKNSTAGGYADHLYGARVAKISVNLKEFLLASMNLT MHO95975/CAV/SK LPNPQSTMTIRFQGIIFLTEGFILPKNSTAGGYADHLYGARVAKISVNLKEFLLASMNLT MHO95973/CAV/SK LPNPQSTMTIRFQGIIFLTERFILPKNSTAGGYADHLYGARVAKISVNLKEFLLASMNLT KC691411CMB1109 LPNPQSTMTIRFQGIIFLTEGLILPKNSTAGGYADHLYGARVAKISVNLKEFLLASMNLT KU195693/IR5-CA LPNPQSTMTIRFQGIIFLTEGLILPKNSTAGGYADHLYGARVAKISVNLKEFLLASMNLT M55918/CUX-1/Ge LPNPQSTMTIRFQGVIFLTEGLILPKNSTAGGYADHMYGARVAKISVNLKEFLLASMNLT AF $313470 / \mathrm{De} 1$ LPNPQSTMTIRFQGVIFLTEGLILPKNSTAGGYADHMYGARVAKISVNLKEFLLASMNLT EF683159/Austra LPNPQSTMTIRFQGVIFLTEGLILPKNSTAGGYADHMYGARVAKISVNLKEFLLASMNLT $\mathrm{KM} 226338 / \mathrm{AO} / \mathrm{j}$ ap LPNPQSTMTIRFQGVIFLTEGLILPKNSTAGGYADHMYGARVAKISVNLKEFLLASMNLT AJ890284/(Nobil LPNPQSTMTIRFQGVIFLTEGLILPKNSTAGDYADHMYGARVAKISVNLKEFLLASMNLT MH095974ICAV/SK LPNPQSTMTIRFQGIIFLTEGLILPKNSTAGGYADHLSGARVAKVSVNLKEFLLASMNLT

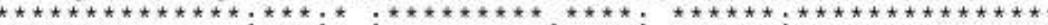

$$
125 \quad 139 \quad 144 \quad 151 \quad 160
$$

MHO95977/CAV/SK YVSKIGGPIAGELIADGSQSQAAQNWPNCCLPLNNNVPSA MH095976/CAV/SK YVSKIGGPIAGELIADGSQSQAAQNWPNCCLPLNNNVPSA MHO95975/CAV/SK YVSKIGGPIAGELIADGSQSQAAQNWPNCCLPLDNNVPSA MH095973/CAV/SK YVSKIGGPIAGELIADGSQSQAAQNWPNCCLPLNNNVPSA KC691411CMB1109 YVSKIGGPIAGELIADGSQSQAAQNWPNCWLPLDNNVPSA KU195693/IR5-CA YVSKIGGPIAGELIADGSQSQAAQNWPNCWLPLDNNVPSA M55918/CuX-1/Ge YVSKIGGPIAGELIADGSKSQAADNWPNCWLPLDNNVPSA AF $313470 / \mathrm{Del}$ YVSKIGGPIAGELIADGSKSQAAENWPNCWLPLDNNVPSA EF683159/Austra YVSKIGGPIAGELIADGSKSQAAENWPNCWLPLDNNVPSA KM226338/AO/jap YVSKIGGPIAGELIADGSKSQAEENWPNCWLPLDNNVPSA AJ890284/(Nobil YVSKIGGPIAGELIADGSKSQAAENWPNCWLPLDNNMPSA MHO959741CAV/SK YVSKIGGPIAGELIADGSQSQTAQNWPNCCLPLDNNVPSA

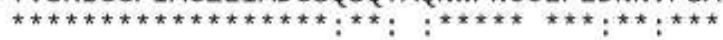

Fig. 4: five fields isolate sequences alignment with six reference including three commercial vaccines. Multiple sequences alignment of the amino acid of residue at position (61-160) of VP1 region including hypervariable region (139-151) and genetic determinates of CAV virulence.

\section{REFERENCES}

Abdel-Mawgod, S., Adel, A., Arafa, A.S. and Hussein, H.A. (2018). Full genome sequences of chicken anemia virus demonstrate mutations associated with pathogenicity in two different field isolates in Egypt. Virus Dis. 29(3), pp.333341.

AboElkhair, M., Abd El-Razak, A.G. and Metwally, A.E.Y. (2014). Molecular characterization of chicken anemia virus circulating in chicken flocks in Egyp. Adv. in virology. ID 797151, 6 pages.

Adair, B.M. (2000). Immunopathogenesis of chicken anemia virus infection. Dev. Comp. Immunol. 24(2-3), pp.247-255.

Al-Mohana, A.M., Kadhimv, H.M., Al-Charrakh, A.H., Al-Habubi, Z., Nasir, F.H., Al-Hilali, S.A. and Hadi, Z.J. (2013). Molecular diagnosis of avian respiratory diseases in commercial broiler chicken flocks in province of Najaf, Iraq. Sci. Res. and Essays. 8(26), pp.1191-1195.

Brentano, L., Lazzarin, S., Bassi, S.S., Klein, T.A.P. and Schat, K.A. (2005). Detection of chicken anemia virus in the gonads and in the progeny of broiler breeder hens with high neutralizing antibody titers. Vet. Microbiol.105(1), pp.65-73.

Cardona, C.J., Oswald, W.B. and Schat, K.A. (2000). Distribution of chicken anaemia virus in the reproductive tissues of specific-pathogen-free chickens. . J. Gen. Virol, 81(8), pp.2067-2075.

Craig, M.I., Rimondi, A., Delamer, M., Sansalone, P., König, G., Vagnozzi, A. and Pereda, A. (2009). "Molecular characterization of chicken infectious anemia virus circulating in Argentina during 2007. Avian Dis. 53(3), pp.331-335.

Gelderblom, H., Kling, S., Lurz, R., Tischer, I. and Bülow, V.V. (1989). Morphological characterization of chicken anaemia agent (CAA). Arch. of virol. 109(1-2), pp.115-120.

Hailemariam, Z., Omar, A.R., Hair-Bejo, M. and Giap, T.C. (2008). Detection and characterization of chicken anemia virus from commercial broiler breeder chickens. Virol. J. 5(1), p.128. n.d. 
Islam, M.R., Johne, R., Raue, R., Todd, D. and Müller, H. (2002). Sequence Analysis of the Full-Length Cloned DNA of a Chicken Anaemia Virus (CAV) Strain from Bangladesh: Evidence for Genetic Grouping of CAV Strains Based on the Deduced VP1 Amino Acid Sequences. J. Vet. Med.Series B, 49(7), pp.332-337.

Jeurissen, S.H., Wagenaar, F., Pol, J.M., Van der Eb, A.J. and Noteborn, M.H. (1992). Chicken anemia virus causes apoptosis of thymocytes after in vivo infection and of cell lines after in vitro infection. J. Virol. 66(12), pp.7383-7388.

Kim, H.R., Kwon, Y.K., Bae, Y.C., Oem, J.K. and Lee, O.S. (2010). "Molecular characterization of chicken infectious anemia viruses detected from breeder and broiler chickens in South Korea. Poultry sci. 89(11), pp.2426-2431.

Kumar, A. (2007) Detection and molecular characterization of chicken infectious anaemia virus from poultry. Doctoral dissertation, Anand Agricultural University, Anand.

Kye, S.J., Kim, J.Y., Seul, H.J., Kim, S., Kim, S.E., Lee, H.S., Sorn, S. and Choi, K.S. (2013). Phylogenetic analysis and genetic characterization of chicken anemia virus isolates from Cambodia. Poultry sci. 92(10), pp.26812686.

Marin, S.Y.G., Barrios, P.R., Rios, R.L., Resende, M., Resende, J.S., Santos, B.M. and Martins, N.R.S. (2012) Molecular characterization of contaminating infectious anemia virus of chickens in live commercial vaccines produced in the 1990s. Avian dis. 57(1), pp.15-21.

Murphy, F.A., Gibbs, E.P.J., Horzinek, M.C. and Studdert, M.J. (1999). Veteterinary virology 3rd Edition. eBook. ISBN: 9780080552033

Noteborn, M.H., Verschueren, C.A., Koch, G. and Van der Eb, A.J. (1998). Simultaneous expression of recombinant baculovirus-encoded chicken anaemia virus (CAV) proteins VP1 and VP2 is required for formation of the CAVspecific neutralizing epitope. J. gen. virol. 79(12), pp.3073-3077.

Peters, M.A., Crabb, B.S., Washington, E.A. and Browning, G.F. (2006). Site-directed mutagenesis of the VP2 gene of chicken anemia virus affects virus replication, cytopathology and host-cell MHC class I expression. 1996. J. gen. virol. 87(4), pp.823-831.

Renshaw, R.W., Soiné, C., Weinkle, T., O'Connell, P.H., Ohashi, K., Watson, S., Lucio, B., Harrington, S. and Schat, K.A. (1996). A hypervariable region in VP1 of chicken infectious anemia virus mediates rate of spread and cell tropism in tissue culture. J. J. Virol. 70(12), pp.8872-8878.

Schat, K.A.,. (2004). Circovirus infections, chicken infectious anemia. In.". Diseases of poultry, 11th ed., Iowa State University Press, Ames, IA. pp. 82-202.

Snoeck, C.J., Komoyo, G.F., Mbee, B.P., Nakouné, E., Le Faou, A., Okwen, M.P. and Muller, C.P. (2012). Epidemiology of chicken anemia virus in Central African Republic and Cameroon. Virol. J. Dec; 9(1):189.

Sommer, F. and Cardona, C. (2003). Chicken anemia virus in broilers: dynamics of the infection in two commercial broiler flocks." Avian dis. 47(4), pp.1466-1473.

Tamura, K., Stecher, G., Peterson, D., Filipski, A. and Kumar, S. (2013). MEGA6: molecular evolutionary genetics analysis version 6.0. Mol. Biol. Evol. 30(12), pp.2725-2729.

Thompson, JD, and DG and Gibson, TJ Higgins. (1994). CLUSTAL W: improving the sensitivity of progressivemultiple sequence alignment through sequence weighting,position-specific gap penalties and weight matrix choice.Nucleic Acids Res. 22: 4673-4680.

Todd, D., Scott, A.N., Ball, N.W., Borghmans, B.J. and Adair, B.M. (2002). Molecular basis of the attenuation exhibited by molecularly cloned highly passaged chicken anemia virus isolates. $J$. of virol. 76(16), pp.8472-8474.

Ucatez, M.F., Owoade, A.A., Abiola, J.O. and Muller, C.P. (2006). Molecular epidemiology of chicken anemia virus in Nigeria. Arch. of Virol. 151(1), pp.97-111.

Yuasa, N., Taniguchi, T. and Yoshida, I. (1979). Isolation and some characteristics of an agent inducing anemia in chicks. Avian Dis.. pp.366385. 